\title{
HUMAN INSECURITY IN THE TWENTY-FIRST CENTURY
}

\author{
EDDIE J. GIRDNER*
}

\begin{abstract}
The spread of neoliberalism around the globe in the last quarter century has greatly increased human insecurity. The United States became a provider not of global security but rather insecurity. The destruction of the environment under the established regime is often seen to be the major source of human insecurity. At a deeper level, however, it is clear that the underlying malady is neoliberal capitalism, the logic of which precludes addressing the demise of the global ecosystem, poverty and hegemonic wars. Mainstream academics have characteristically saluted the neoliberal agenda and proceeded to reinforce and propagate the ideology underlying the deceptive mantra that there is no alternative. Human security is sorely lacking in a world where people are being vaporized by increasingly horrible forms of bombs, where about half of the population make less than two US dollars a day, where urban slum colonies proliferate, and where war budgets eat up ever larger portions of national state budgets.
\end{abstract}

\section{KEYWORDS}

Environment, Financial Terrorism, Global Poverty, Human Security, Neoliberalism, United States, War

*Eddie J. Girdner, PhD, is a Professor in the Department of Political Science and International Relations, Başkent University, Ankara, Turkey. 
The socialist dream was the faith that human kind would have the wisdom not to destroy itself through capitalist greed. So far, we cannot say that there is very much evidence that this is the case. What we have seen in the last three decades is the unleashing of that greed through the forcing upon the world of a system of so-called neoliberalism. Some aspects are new but it is not liberal. Under this regime, no effort has been spared to crush the utopian dreams, to make sure that this faith has been discarded beyond repair never to rise again from the ashes of its demise. The only consolation is that the global powers pushing this new vision of global totalitarian rule are themselves reaching their demise as history passes their collapsing empires by. Most notably, the United States, whose power grab on an unprecedented scale, has blown up in its face and strengthened rival powers. ${ }^{1}$ In late 2008 , rather than provide security to the international community, the excesses of greed on Wall Street brought down the global financial system. After preaching to the entire world about the need to nationalize their banks, the Government of the United States of America was seen scrambling to nationalize its own banks. The lesson should be obvious to policymakers around the world.

The post World War II myth was that the US would be the provider of global security. In fact, what history has shown is that global empires cannot provide security even to themselves. A superpower on the decline may become a provider of global insecurity as its historical global declining.

\section{Human Security and the Environment}

Human security, or the security of the people, is sometimes seen to be focused upon the environment, particularly the effects associated with global warming from greenhouse gas emissions such as nitrogen oxide, carbon dioxide, and methane. The polar ice caps are melting faster than anyone previously imagined. Storms such as catastrophic hurricanes are more frequent and many types of unusual weather patterns are occurring. Al Gore's film, "An Inconvenient Truth" has brought these phenomena to the attention of the world.

${ }^{1}$ Eddie J. Girdner, USA and the New Middle East, New Delhi, Gyan Publishers, 2008. 
No doubt these effects constitute serious threats to human security, but of course more often to the very poor around the world than to others. They are seriously important, but this paper will not focus upon the environment. This is because it is a problem that in my view is not going to be solved, although there will be a good deal of tinkering over the problem.

This approach is quite pessimistic, but in my view, the problem simply cannot be addressed under the present system of neoliberal capitalism. This is because preserving and protecting the environment contradicts the fundamental logic of profits and significant economic growth. ${ }^{2}$ Just to stabilize global warming, emissions would have to be cut by some 50 percent. This is simply not going to happen under the present global economic system. Even the most efficient countries will not do this, much less the greenhouse gas champion of the world, the USA. Nor will China and India significantly cut greenhouse gas emissions, as they need a high rate of economic growth and have massive populations. Corporate profits will always win out as long as the present system of global economy based upon profits and capitalist accumulation is in place.

Nor will citizen action make very much difference. Big corporations will act quickly to neutralize efforts by more environmentally aware citizens. Green-washing ads now paint oil corporations, such as Shell and Exxon, as pioneers in environmental preservation. The public relations industry has proven to be highly effective in spreading corporate lies and business propaganda. Big corporations cannot kill the environmental movement, but they can partially co-opt it, using it to conceal some of their sins. When they really meet serious challenges, they sue in courts. They move into every niche to pollute more and increase their profits. Governments, for the most part, act in complicity with big corporations, encouraging them to move away from highly polluted areas and into clean areas, so as to pollute even more. In the same way, polluting corporations exploit ignorance and lack of environmental awareness. When McDonalds is stopped from using ozone- damaging Styrofoam

${ }^{2}$ Eddie J. Girdner and Jack Smith, Killing Me Softly: Toxic Waste; Corporate Profit and the Struggle for Environmental Justice, New York, Monthly Review Press, 2002. 
containers in the US by environmentalists, the company rushes the same polluting materials to third world countries to continue to degrade the environment the same way there. In other words, these corporations know they are killing the earth, but they proceed to bulldoze their way forward to kill it ever quicker to sustain their profits. They may post some pictures of green trees as a further insult to people's intelligence, as British Petroleum (BP) has painted its petrol stations with yellow and green and painted flowers upon its walls. But without some alternative economic system which is not based upon the logic of capitalism, we can "kiss the environment good bye."

Rather, this paper will focus upon a somewhat different contradiction. The deeper malady is neoliberalism. At the same time, there is a contradiction between "national security" and "human security." This is seen in war and imperialism.

Today, to focus upon "human security" is seen as something new, but I do not really believe that this is true. In the past many writers have focused upon this issue but have simply been ignored. The concerns of the lesser people generally have been pushed aside throughout history. History seldom records how many innocent people die in the fray. This is so, it seems, because history, international relations, international politics, and so on, have generally been viewed from the ruling class point of view.

\section{The Pressure to Avoid the Truth in Academia}

Academics and thinkers who focus upon the truth, rather than serving the ideological needs of the ruling class, are generally dismissed out of hand. They will generally not be able to easily publish, at least not in prestigious journals and presses, which they need in order to advance their careers. Those academics who do serve the ruling class interests and ideology and are quite quickly proven to be wrong, usually do not suffer any negative consequences. On the other hand, those academics who were correct all along, but unable to publish in prominent places, will get little or no credit for being correct. 
A clear example comes to mind. Francis Fukuyama became one of the world's most famous scholars by pushing false and foolish views about neoliberalism in the 1990s. The new "liberal" was to be in style from now on. "The End of History and the Last Man" had to be mentioned by everyone as a work of great erudition. A decade later, even the United States of America was seen to nationalizing its major banks and the era of neoliberalism had devastated countries and people around the world. Neoliberalism was failing in even being able to sustain itself as a viable global economic system. It is a major disaster economically, socially, and environmentally. It is a system which cannot long work and is being challenged increasingly. ${ }^{3}$ Yet, academics like Fukuyama maintain their elite status at prestigious universities, while those who were honest and correct in their criticism never gain recognition. Actually, it was the Marxists who mainly criticized Fukuyama and they have been proven correct. Yet who has asked Professor Fukuyama to account for his predictions which have turned out to be so erroneous. It is not seen to matter as his ideas were put forward in good faith in his duty of shoring up the capitalist ideology of the ruling class.

The Monthly Review school in New York very accurately chronicled the condition of the American economy and the likely consequences of the build-up of massive household debt in its publications. Yet, the academic establishment, as a part of the ruling class, often avoids acknowledging the truth about the economic system. Economists often cling to an ideology of the free market, when it has little to do with facts in the real world. Because of this, universities and academics frequently neglect their duty and public trust to make the public aware of the truth, even when it contradicts ideology. Chalmers Johnson is one of the many exceptions to this trend in his recent probing of the American Empire. ${ }^{4}$ Noam Chomsky, known around the world, but not very well in America is another example. Joseph Stiglitz in his criticism of IMF programs and the disaster of the inordinate costs of the American-led wars in Afghanistan and Iraq is another example of honest scholarship,

${ }^{3}$ Eddie J. Girdner and Kalim Siddiqui, "Neoliberal Globalization, Poverty Creation and Environmental Degradation in Developing Countries", International Journal of Environment and Development, Vol. 5 (1), 2008, pp. 1-27.

${ }^{4}$ See his trilogy on the American Empire. 
reported in such a way that non-academics can understand what is really going on.

When academics in the social sciences, who have the responsibility to study society and be honest about the degradation brought about by actually existing neoliberal capitalism, jump on the ideological bandwagon and advance their careers by advancing the ruling class ideology, they become guilty of contributing to human insecurity. When they promote privatization of social security, pension schemes, medical benefits, under the argument that all will be better off, then they have the responsibility to show whether it is actually empirically true. Millions of individuals under neoliberal privatization schemes saw their pension plans robbed of value by greedy capitalists across the world in late 2008 . When academics taut the market, as the salvation for society, they greatly increase global human insecurity. The people are told to trust the market. Yet when the market fails, Wall Street, stock traders, politicians, bankers, and all the so-called free marketers rush to be saved by the state.

Academics have an ethical responsibility to tell the truth in the textbooks. Yet the real function of universities is to reproduce the ruling class and the ruling ideology. Students are not to learn that the only way that capitalism can be kept afloat is by being rescued periodically by the state. They are not to understand that the people are being robbed over and over. They are robbed when the system collapses and they lose what little wealth they have built up. They are robbed a second time when they pay taxes to bail out the bankers whose greed collapses the enterprises. How long will such a system be considered to be "just?"

\section{War and Human Insecurity}

War has been about what happens to the state, not about what happens to the people. Who cares about the people? For Robert Fisk, war is really about what happens to the people, that is, the tragedy of all wars. "War is primarily not about victory of defeat but about death and the infliction of death. It represents the total failure of the human 
spirit." "We created a desert and called it peace." This from a Celtic Chieftain about the Romans illustrates the aftermath of war from past history. The people have always been caught up in armies creating deserts.

What kind of human security is it when one's city gets vaporized with an atomic weapon as with Hiroshima and Nagasaki? What kind of human security is it when one's country is drenched with chemical weapons? One gets fried alive if that chemical is napalm, which the US used in Korea and Vietnam and again illegally and secretly in Iraq. What kind of human security is it when mass graves are created by killing civilians who are suspected of having communist sympathies, such as is now coming to light in South Korea? What kind of human security is it when the US sponsored death squads in El Salvador killed peasants who wanted freedom from exploitation from landlords and dumped their bodies in ravines? What kind of human security is it when villagers are bombed and killed in Pakistan and Afghanistan under the name of a "war on terror." The dead are cynically referred to as "collateral damage" while foreign forces in their countries claim to be providing "security."

The greatest inventor and the greatest user of weapons of mass destruction (WMD) in history is a long way from being the late Saddam Hussein. In fact, WMD represents prestige, power and national strength in realist state logic. It is highly honorable to be a warrior and to kill, as noted by Thurstein Veblen. ${ }^{6}$ The napalm or jellied petroleum which the US used massively in Korea and Vietnam burns off people's skin. And the US sprayed Vietnam with Agent Orange, a form of toxic dioxin which is still killing people. The US used napalm, burning people alive in Fallujah in Iraq, secretly and against international law. The Balkans and Iraq are now massively polluted with depleted uranium, which is far from being depleted. Depletion takes some 4.5 billion years. People will be suffering in both regions for a long time to come. Yet all of these wars were seen to come under the category of providing global security.

${ }^{5}$ Robert Fisk, The Great War for Civilization: The Conquest of the Middle East, New York, Alfred A. Knopf, 2006, p. xviii.

${ }^{6}$ Thurstein Veblen, The Theory of the Leisure Class, New York, Dover Publication, 1994. 
Notably, I.F. Stone wrote about the US carpet bombing of villages in Korea with napalm during the Korean War. ${ }^{7} \mathrm{He}$ argued that there was no compelling military reason for using napalm to destroy people and kill innocent civilians. Many villages were said to be "enemy occupied" and given "saturation treatment" when it was thought that there were a few North Koreans in the villages. This is really little different from the Vietnam War and the US occupation of Iraq today. It is seen in the destructive Israeli bombing of residential areas of Lebanon in 2006 and the killing by the Israel Defense Forces of Palestinians in Gaza and the West Bank.

In the case of Korea, there was "a complete indifference to non-combatants" in each case, when families were bombed and vaporized in the villages. They were just collateral damage, which is a form of dehumanization and objectification of living human individuals.

Stone cites a dispatch from a New York Times correspondent about the napalm bombing of a village in North Korea. "A napalm raid hit the village three or four days ago... and nowhere in the village have they buried the dead because there is nobody left to do so... the inhabitants throughout the village and in the fields were caught and killed and kept the exact postures they had held when the napalm struck- a man about to get on his bicycle, fifty boys and girls playing in an orphanage." A captain said: "You can kiss that group of villages good-bye." The US Air Force reported "excellent results."

Villages are still being kissed good-bye in the name of "national security." From the military standpoint, it was indeed excellent. But what kind of human security is that? It is very much like what the United States said about the ancient city of Hue in Vietnam. "We had to destroy the city to save it."8 Again, this was said when the US military destroyed the city of Fallujah in 2004 to kill or drive out members of al-Qaeda. Every city in the whole of

${ }^{7}$ I. F. Stone, The Hidden History of the Korean War 1950-51, Boston, Little Brown, 1988, [Originally published by Monthly Review Press in 1952].

${ }^{8}$ The exact phrase was repeated when the US military attacked and destroyed the city of Fallujah in Iraq in November 2004 as punishment for the killing of the four mercenary Blackwater guards a few months before. 
Korea was bombed. The whole country was almost totally destroyed. The Korean War was officially a "police action" but killed between three and four million people. The Vietnam War killed another three million. In Iraq, at least another three million have died, since the first Gulf War in 1991. Now in Afghanistan President Hamid Karzai is upset over the killing of innocent civilians as villages are bombed by US forces and NATO forces. In August of 2008, some 90 civilians died in one village, about 60 of them being children. This bombing by US forces has now spread to Waziristan in Pakistan. In Columbia in the drug war and in Nicaragua in the Contra War in the 1980s, many innocent civilians were killed. All of this is said to be for "national security."

Now in late 2008, American officials continue to say the US must "win" in Iraq and if they don't win, the Iraqis will follow them home! On the other hand, it was not the Iraqis who asked the Americans to come and occupy their country. Human security is always under threat. After Iraq, every country hoped that the United States would choose a country different from their own in which to "promote democracy."

Today, the threat is more serious than ever. In a recent book, Hegemony or Survival, Noam Chomsky considers whether the human species will survive. There were certainly grave threats of a nuclear holocaust during the Cold War. Chomsky cites the biologist Ernst Myer who notes that in terms of human survival, beetles and bacteria are vastly more successful in terms of survival than humans. It may be that humans have used their 100,000 years on earth to destroy themselves and their time on earth is about to be ended. The average life of a species is about 100,000 years. This means that in terms of survival of a species, it is better to be stupid than smart.

\section{Capitalism, Neoliberalism and Human Insecurity}

Beyond war and imperialism, there is a very fundamental and deeper contradiction between neoliberalism, capitalism and human security. But neoliberal globalization, the contemporary form of capitalism, hides this reality. And today, the promoters of neoliberal capitalism are very proud of the achievements of capitalism. Yet in 
this system, even capital is not secure, in spite of all the big guns at its disposal, let alone human security.

Francis Fukuyama thought that the world had reached the "end of history," the ultimate human achievement with this sort of liberalism. "The last man," the neoliberal rational individual might actually end up being the last man if history continues on its present deadly course. Of course, we have not reached the end of history. There are some simple facts which are either not mentioned or conveniently forgotten, which give us some indication of the success of global capitalism over the last half century or so.

Since the end of the developmentalist era in the 1950s and 1960s, world economic growth has slowed to about half, from 5 percent annually to some 2.5 percent. ${ }^{9}$ Global corporate profits, on the other hand, had soared until the economic crises in late 2008. Global inequality has grown by leaps and bounds. This is a major source of human insecurity. In fact, global inequality is now the greatest in human history. Between rich and poor countries, the ratio of standard of living was only about three to one in 1820. It is now often said that Karl Marx was wrong and is irrelevant, but this is exactly what he predicted some 150 years ago. The increasing pauperization is seen around the world today. The richest one percent of the world's people receives about the same income as the bottom 57 percent. The richest 50 individuals have more income than the poorest 416 million. About one percent own some 80 percent of the world's wealth. This is called privatization, but it is actually closer to pirateization, as most of the world's wealth is actually produced by the poor.

Today, most of the world's population cannot live on the income they receive. At least 40 percent of the global population,

\footnotetext{
${ }^{9}$ The IMF warned of even slower global growth in the wake of the global financial economic crises in late 2008. The George W. Bush Administration, which almost everyone in the entire world was waiting anxiously to see end, still had enough clout to extend its invisible hand and deal a hard whack to just about everybody in every country around the globe. There seemed to be no place or no market in which to hide. Ironically, after so much touting of the free market, the state seemed to be the only refuge for the Bush-beleaguered of the globe.
} 
which comes to 2.5 billion people, makes less than two US dollars a day. Millions live in slums. In India, thousands of farmers have committed suicide because they could not bear to live on their miserable existence. On the other end of the scale, in top companies in the US, company heads make from 1000 to 2000 times as much as their employees. It seems that they have very large brains, are terribly creative and always go business class, so they deserve it. It recently emerged, after the collapse of Lehman Brothers Bank, that Richard Fuld, who headed the company, was compensated by 480 million dollars over eight years. Americans were outraged by such greed when they were asked to work and give their tax dollars to bail out these banks, but the bankers were unrepentant. When AIG Insurance Company was bailed out by the US Government around the same time, the executives celebrated with a party costing over 400,000 dollars.

And inequality is getting worse around the world, or better, depending on whether one is in business class or the other class. Capitalists say they do not believe in class analysis but seem to in practice on airplanes and airport lounges, where the class which controls capital is strictly segregated from the rest of the people in "business class." Brains, of course, have nothing to do with it. It is strictly according to one's relation to "business," that is, capital. The ratio of the top five percent to the bottom five percent was 78 to one in 1988. By 1993 it was 114 to one. This has only increased since. Financial crises, such as the financial crises in late 2008, generally have the effect of increasing inequality. The wealthiest investors with cash are salivating over the chance to acquire "distressed assets" cheaply. They will emerge with greater wealth when the crisis subsides.

With such a system, the banks also get a chance to rob the people twice. First they rob them of the money they have put in the bank. What else could dipping out 480 million dollars by a single individual on the way to bankrupting the bank honestly be called? The people are robbed again when they are asked to pay taxes to bail the banks out from their excesses. The state has to step in to ensure the continuation of capitalist accumulation when the greed on Wall Street has killed the capitalist goose. Back in business, the banks proceed to robbing the public again with a fountain pen by issuing more loans, with little or nothing to back them up. 
But is it not true that globalization is closing this income gap today, as we are told, and as neoclassical economic theory predicts? The answer, of course, is "no." According to one source, only 9 countries (4 percent of the world's population) have reduced the wealth inequality gap. In the USA, the wealthiest country by some measures, one person in eight lives in poverty. Of the 100 wealthiest entities around the globe, only 48 are countries and 52 are big corporations. This is generally admitted to be morally unacceptable.

\section{Financial Terrorism}

Corporate security is a different matter, really. When people are going bankrupt without jobs and losing their homes, this is a problem for the market to solve. When corporations are going bankrupt, it is a different matter. Governments care about corporate security, as opposed to human security, under the current system of "socialism" for big corporations and capitalism and the market for the little people. The system of "socialism for the rich" and the politicians and capitalism for the masses is firmly in place. When the banks run out of money, they are said to "cash strapped" and are refunded with billions from the central banks or taxpayers. The term "cash strapped," of course, is never noted as a condition of the people. It is measured rather as "a drop in consumer confidence" or "weak demand." But large doses of "socialism" are quickly forthcoming for the banks in the UK and the United States. When things really got bad, Congress was asked to approve a bailout package of more than 700 billion dollars for the system. Of course, it is not "socialism for the rich." It is better described as financial fascism of financial terrorism, as noted by the critical economist, Max Kaiser.

Corporate profits, of course, are not about to be socialized. Over the last three years, from 2005 to 2008, corporate profits are up 60 percent while incomes have generally fallen in real terms. The incomes of most have risen at most by ten percent in nominal terms. In the economic downturn, tens of thousands are losing their jobs in practically every country.

Indeed, we cannot deny that the results of actually existing neoliberal capitalism are very impressive indeed. No other economic 
system in history has produced such results, which include the following: fully half of all humanity is malnourished; a billion people live in slums; about half the world's population live on less than two US dollars a day; a billion people have no access to clean water; two billion (one third) have no electricity; two and a half billion have no sanitary facilities; one half of all children (one billion) suffer greatly through poverty, war and disease; those made homeless inside Iraq due to the US imperialist occupation now number 2.7 million; and there are at least three million who have fled to neighboring countries. The list could go on and on. The world's CEO's have shown their talents in their contributions to producing such conditions and surely deserve their inordinately high salaries. But what kind of human security is this?

More than half the world's population is being terrorized by neoliberalism. They had nothing to fear from socialism or communism during the cold war and have nothing to fear from Islamic terrorism today. The war on terror for them, if there was indeed such a thing, would be a war on capitalism and its present form, neoliberalism. Such words as emanate from the mouth of western politicians about a war on terror is completely incomprehensible to at least half of the world's population. They live in the extreme of human insecurity provided by the global economic system.

It may be seen as "national security" or security for capital. To be fair, capitalism has often produced a high "gross national product," a "very gross national product" as Edward Abbey, the American environmentalist and anarchist, said. ${ }^{10}$

\section{Providing "Security" and Historical Decline}

Capitalism eventually runs itself into the ground. It happened once again in late 2008, with the scramble to put the shattered Humpty Dumpty of trilateral capitalism back on the Wall. The people were told to stand still and be patient while the bankers fleeced them of their hard-earned pay for decades into the future. All the focus of

${ }^{10}$ Edward Abbey, Confessions of a Barbarian, Boston, Little Brown, 1994. 
the TV cameras was on the fictitious numbers of stock prices on Wall Street, while little attention was paid to the real economy, which would drive people to the wall without homes and employment. The US under illegal pretext had, in the name of providing security, squandered a trillion dollars on an imperialist war in Iraq enriching American private corporations with profits to the tune of billions of dollars. But President George W. Bush was rapidly collapsing the American Empire.

Meanwhile, however, the countries which are over the hill, historically, which include the G-7, cannot generate enough jobs for their own people under capitalism. These are the historical relics, the old European countries, the now fallen former "Great Powers." And increasingly, the US is headed south in more ways than one to join them on the scrap heap of history. So, they live off the labor of the rest of the world, and the products other countries produce. The European Union colonizes more countries in the east of Europe and the US lives off the labor of China. The US has been reduced to borrowing some one billion dollars a day to carry on its colonialist wars for the control of gas and petrol. Today, the former socialists in China (with a de facto state-guided capitalist economy but named "market socialism") save the American capitalists from their folly. The US never knew how much it needed Chairman Mao until it had to fight wars in Afghanistan and Iraq on the Chinese credit card after George W. Bush had given all the money in the US treasury to his rich business friends, including the firms controlled by the Bush family itself.

This is not true of all countries, to be fair. Some try to change the system to provide for all, guaranteeing jobs and social welfare. Namely, they promote genuine human security. But they get in trouble with Texas. This, of course, is opposite of "reform" as it is being carried out around the world today, which means shifting social welfare from the needy in society to big corporations to bolster capitalist accumulation. This is what they are supposed to be doing, how they are supposed to be "reforming" the system. Following the dictates of the IMF, which works as a sort of rapid unemployment force to be deployed around the world, states tend to impoverish their own populations. The cost of neoliberalism to the global population, in loss of jobs and social welfare, in terms of human insecurity, has not been calculated. 
The sort of real reform which bolsters genuine human security is not the "market way" of doing things. Hugo Chavez in Venezuela is making reforms to bolster the welfare of the people. This is a real measure of democracy. And it makes him, instantly, an enemy of the United States of America, and, to a lesser extent, those imperialists who trail in their wake, namely the European Union and Japan. When Chavez holds a referendum, loses and accepts the results, he is called "authoritarian. In short, his efforts to guarantee human security are met with extreme hostility from the powers that be. Indeed, the US organized a coup against him, but it failed because a million people came into the streets and demanded that he be put back into power. US policy toward Venezuela is driven not by concern for the people, but concern for capital and resources, notably oil.

Perhaps it is not fair to criticize poor countries for their lack of human security. They often do not have the capacity. But when we look at the rich countries, this may be a better test. There are, in fact, large differences between the developed countries, between the US and Europe. In terms of social welfare, the US wins hands down, that is, in cheating their people out of the social welfare and conditions which rightly belong to them. They are at the flat bottom in almost any measure of human welfare among the developed countries. Moreover, they do not mind their own business but force other countries to follow in their wrong policies which deprive people of their democratic rights.

Michael Moore's recent film, "Sicko" illustrates this well. The lack of social medicine in the United States is a genuine disgrace. At least 50 million Americans have no health insurance at all. But even having full private health insurance does not provide security. Half the bankruptcies in the US are caused by medical bills which families cannot pay. And three-quarters of those claiming bankruptcies due to health bills have full health coverage, but the insurance companies do not pay. This deplorable public policy of neglecting public health in the United States contributed greatly to bringing the entire global financial system down in late 2008. People could not pay both their inordinate medical bills and their mortgages at the same time.

The solution to America's health problem is simple. The United States does not even have to invent a new system. US 
policymakers could just adopt one of the systems which work well in Canada, the UK, or France. But this is not going to be done in the US. Why? Because of the power of capital, the profits of the pharmaceutical industry and the privatization of the medical insurance industry. To be sure, many sectors of US business would actually benefit from a single payer government health insurance system, but these industries are simply too powerful. The US government is not independent enough from these industries to bring such a system into being. So their profits must be preserved. This means that any reform, such as those proposed by the Presidential candidates Barack Obama and John McCain, will be inefficient and continue to reap huge profits from the American people.

If the government is involved in doing something for people's health, it is seen as "socialized medicine" and an evil. Bailing out private banks with billions of taxpayers dollars, of course, is a totally different thing! In the prevailing neoconservative philosophy, the government is there to serve the interests of business and capitalist accumulation and not the people.

If capitalists really trusted the market, why would they send 25,000 lobbyists to Washington to shill for big corporations. Priorities are business security and national security, and not "human security." National security has always been synonymous with protecting the profits of global corporations. The people must rely on the "market" but the government is always there to rescue big business. They expect it, since they have bought it and owned it. This is sort of a modern neoliberal social contract. But beyond this, today, what is known as "national security" has bankrupted America and the people.

The US has some one-thousand military bases around the world. The national debt is 9.7 trillion dollars and will reach almost 11 trillion dollars by the time George W. Bush leaves the White House. This is up from five billion when he took office eight years before. The US is currently spending 15 billion dollars a month on two wars, giving every family of four a debt of $\$ 120,000$. At least 90 percent of so-called defense spending goes straight to corporate profits. As war is privatized, for corporate profits, the country must stay at permanent war. With the sub-prime mortgage crises, some one million families in America have lost their homes and another million 
are in danger of losing them. And when a disaster like Hurricane Katrina strikes, the US government says it lacks the resources to help.

In fact there is human insecurity almost everywhere with violence and human misery such as in Darfur. In the end, human security is part of environmental disaster. Human individuals are a part of nature. But they, of course, have a very low status compared to commodities like oil. If the world under the current system of neoliberal capitalism has so little concern with the human part of nature, what will be the fate of the rest of nature? Unfortunately, the priorities lie elsewhere.

\section{Conclusion: The US as the Provider of Global Security?}

The truism that America has been the provider of global security in the world since World War II should be questioned. Initially, the existence of Communist countries forced the western countries to provide a degree of social welfare. The Bretton Woods institutions put limits on the international flow of capital and exchange rates. Neoliberalism has largely wiped out these redeeming features which contributed to a degree of human security.

At the same time, the United States was at the head of the trilateral system of capitalist nations which was determined to roll back any efforts by emerging nations to establish alternatives to neoliberal capitalism. Counterinsurgency was used to roll back people's democratic revolutions. Today the so-called "war on terror" is a continuation of these efforts to preserve the hegemony of the trilateral group of nations. Considering the enterprise of saddling the globe with neoliberalism and depriving people of social welfare, under a totalitarian global agenda, it may be more accurate to view the United States as the primary provider of human insecurity in the post-war world. 